Original Article

\title{
Inheritance of seedlessness and the molecular characterization of the INO gene in Annonaceae
}

\author{
Herança da ausência de sementes e a caracterização molecular do gene INO em \\ Annonaceae
}

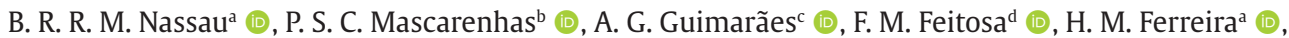 \\ B. M. C. Castro ${ }^{\mathrm{d}^{*}}$ (D) J. C. Zanuncio ${ }^{\mathrm{d}}$ (D), M. R. Costa ${ }^{\mathrm{a}}$ (D) and S. Nietsche $\mathbb{C}^{\mathrm{B}}$ \\ aniversidade Federal dos Vales do Jequitinhonha e Mucuri - UFVJM, Departamento de Agronomia, Diamantina, MG, Brasil \\ bUniversidade Estadual de Montes Claros - UNIMONTES, Departamento de Ciências Agrárias, Janaúba, MG, Brasil \\ 'Universidade Federal da Grande Dourados - UFGD, Departamento de Agronomia, Dourados, MS, Brasil \\ dUniversidade Federal de Viçosa - UFV, Instituto de Biotecnologia Aplicada à Agropecuária - BIOAGRO, Departamento de Entomologia, Viçosa, \\ MG, Brasil \\ eUniversidade Federal de Minas Gerais - UFMG, Instituto de Ciências Agrárias, Montes Claros, MG, Brasil
}

\begin{abstract}
The inheritance of the seedless fruit characteristic of Annona squamosa has not yet been explained. Molecular techniques may aid breeding programs, mainly in the assisted selection of the target gene. The INO gene may be related to seed development in these fruits. The objective of the present paper was to investigate the inheritance of seedlessness in the 'Brazilian seedless' sugar apple and INO gene conservation in Annona squamosa and Annona cherimola $\mathrm{x}$ Annona squamosa genotypes by assessing their homology with the INO database genes. The $\mathrm{F}_{1}$ generation was obtained by crossing the mutant 'Brazilian seedless' (male genitor) $\left(\mathrm{P}_{1}\right)$ with the wild-type $A$. squamosa with seeds ( $\mathrm{M}_{1}$ and $\mathrm{M}_{2}$, female genitors). The INO gene was studied in mutant and wild-type A. squamosa $\left(\mathrm{P}_{1}, \mathrm{M}_{1}, \mathrm{M}_{2}\right.$ and $\mathrm{M}_{3}$ ) and in the Gefner atemoya (A. cherimola x A. squamosa) $\left(\mathrm{M}_{4}\right)$ cultivar. The DNA was extracted from young leaves, and four sets of specific primers flanking the INO gene were amplified. The seedless characteristic was identified as stenospermatic in the fruits of parental $\mathrm{P}_{1}$, suggesting monogenic inheritance with complete dominance. High sequence similarity of the INO gene amplifications in the sugar apple accessions $\left(\mathrm{M}_{1}, \mathrm{M}_{2}, \mathrm{M}_{3}\right)$ and the atemoya cultivar Gefner $\left(\mathrm{M}_{4}\right)$ reinforces the hypothesis of their conservation.
\end{abstract}

Keywords: Annona cherimola x Annona squamosa, Annona squamosa, genetic improvement.

\section{Resumo}

A herança da característica de fruto sem sementes de Annona squamosa ainda não foi esclarecida. Técnicas moleculares podem auxiliar em programas de melhoramento, principalmente na seleção assistida do gene de interesse. $\mathrm{O}$ gene INO pode estar relacionado ao desenvolvimento da semente dessas frutas. $\mathrm{O}$ objetivo foi investigar a herança da ausência de sementes em Annona squamosa e a conservação do gene INO nos genótipos Annona squamosa e Annona cherimola x Annona squamosa avaliando sua homologia com banco de dados de genes INO. A geração F1 foi obtida pelo cruzamento do mutante 'Brazilian seedless' (genitor masculino)(P1) com o tipo selvagem com sementes (A. squamosa) (M1 e M2, genitores femininos). O gene INO foi estudado em A. squamosa, mutante e selvagem (P1, M1, M2 e M3) e na cultivar Gefner atemoya (A. cherimola x A. squamosa) (M4). O DNA foi extraído de folhas jovens, e quatro conjuntos de primers específicos flanqueando o gene INO foram amplificados. A característica sem sementes foi identificada como estenospermática nos frutos do parental P1, sugerindo herança monogênica com dominância completa. A alta similaridade de sequência das amplificações do gene INO nos acessos de pinha (M1, M2, M3) e na cultivar de atemóia Gefner (M4) reforça a hipótese de sua conservação.

Palavras-chave: Annona cherimola x Annona squamosa, Annona squamosa, melhoramento genético.

\section{Introduction}

Annona fruits are tasty, with a sweet, creamy flesh and fragrant flavor when fully ripe (Pareek et al., 2011) in addition to presenting bioactive components with medicinal potential (Vilar et al., 2008, 2011; Quílez et al., 2018). However, the development of seedless varieties of these plants adapted to Brazilian conditions remains limited (Pereira et al., 2019).

The Annonaceae Germplasm Bank at the Universidade Estadual de Montes Claros (UNIMONTES) has potential for breeding programs for these plants. The Brazilian seedless

*e-mail: barbaramcastro@hotmail.com

Received: December 10, 2020 - Accepted: February 4, 2021 
cultivar, originated from a natural mutation, is the only seedless A. squamosa cultivar developed in Brazil, but it has an irregular shape and low yield and commercial value (Pereira et al., 2014).

An aspermic $A$. squamosa variety designated 'Thai seedless' produces normal size, seedless fruits following pollination. The stenospermy in this mutant is due to the suppression of the INO gene, leading to a loss of the outer integument of the ovule, which affects seed development (Lora et al., 2011). The first reports regarding the aspermic condition of the 'Brazilian seedless' variety appeared starting from 2014, together with the stenospermy type, which may be related to the suppression of the INO gene (Santos et al., 2014).

The transfer of the seedless characteristic from A. squamosa 'Brazilian seedless' to atemoya genotypes with potential for commercialization could improve fruit tree crops. This makes it necessary to understand the inheritance of the characteristic and INO gene conservation in Annonaceae as the mechanism of stenospermy and the occurrence of seedlessness in this family.

The objectives of the present study were to investigate (1) the inheritance of the seedless characteristic in A. squamosa and (2) study the conservation of the INO gene in genotypes of sugar apple and atemoya plants with seeds by measuring their homology with the INO genes deposited in a database.

\section{Material and Methods}

\subsection{Plant materials and the inheritance of the seedless characteristic in A. squamosa}

The inheritance of the seedless fruit characteristic was evaluated in two accessions of seeded A. squamosa $\left(\mathrm{M}_{1}\right.$ and $\left.\mathrm{M}_{2}\right)$ and one seedless cultivar, the Brazilian seedless $\left(\mathrm{P}_{1}\right)$. The INO gene conservation was evaluated in another seeded sugar apple accession $\left(\mathrm{M}_{3}\right)$ and in the genotype of the cultivar Gefner atemoya $\left(\mathrm{M}_{4}\right)$ of the Annonaceae Germplasm Collection at UNIMONTES, Campus Janaúba (1547'50”S, 43¹8’31”W, 516 m), Minas Gerais, Brazil.

The $\mathrm{F}_{1}$ generation was obtained with the male genitor of the Brazilian seedless cultivar $\left(\mathrm{P}_{1}\right)$ and the female of two accessions of $A$. squamosa with seeds $\left(\mathrm{M}_{1}\right.$ and $\left.\mathrm{M}_{2}\right)$.

The $A$. squamosa tree seedlings $\left(\mathrm{M}_{1}, \mathrm{M}_{2}\right.$ and $\left.\mathrm{P}_{1}\right)$ were produced from cuttings in a nursery and the $\mathrm{F}_{1}$ generation with the seeds harvested from the fruits from the artificial hybridizations. The plant materials were planted at UNIMONTES in August 2009, with five meters between rows and three meters between plants. The presence or absence of seeds in fruits from the $\mathrm{F}_{1}$ generations of the two crosses $\left(P_{1} \times M_{1}\right.$ and $\left.P_{1} \times M_{2}\right)$ and their respective parents $\left(P_{1}, M_{1}\right.$ and $\left.M_{2}\right)$ were evaluated in the fifth, sixth and seventh years after planting the $\mathrm{F}_{1}$ seedlings in 2014 , 2015 and 2016, respectively.

Genotyping to verify INO gene conservation- The DNA was extracted from young leaves of the three seed A. squamosa accessions $\left(\mathrm{M}_{1}, \mathrm{M}_{2}\right.$ and $\left.\mathrm{M}_{3}\right)$, the seedless A. squamosa (Brazilian Seedless, $\mathrm{P}_{1}$ ), the $A$. cherimola $x$ A. squamosa atemoya cultivar $\left(\right.$ Gefner, $\mathrm{M}_{4}$ ) and the $30 \mathrm{~F}_{1}$ of each progeny of the two crosses $\left(\mathrm{P}_{1} \times \mathrm{M}_{1}\right.$ and $\left.\mathrm{P}_{1} \times \mathrm{M}_{2}\right)$ with the hexadecyltrimethylammonium bromide (CTAB) buffer method (Doyle and Doyle, 1990) associated with the purification of polysaccharides (Cheung et al., 1993).

DNA samples were submitted to amplification reactions (PCR) with specific primers PCR-LMINO 01/02, LMINO 03/04, LMINO 05/06 and LMINO 07/08 (Lora et al., 2011). The sequences available in GenBank for the A. thaliana INO gene were amplified to confirm its presence or absence in the accessions. A specific primer from the ACC gene (1 aminocyclopropane-1-carboxylate synthase) was also amplified as a control.

PCR reactions were performed on Techene TC-412 thermocyclers with a program of 35 cycles with the following temperatures and periods: initial denaturation at $94{ }^{\circ} \mathrm{C}$ for three minutes, 35 cycles at $94{ }^{\circ} \mathrm{C}$ for 30 seconds, annealing temperature of each primer for 30 seconds and extension at $72{ }^{\circ} \mathrm{C}$ for 40 seconds, and final extension at $72{ }^{\circ} \mathrm{C}$ for 4 minutes. The final volume per sample was $25 \mu \mathrm{L}$ with $50 \mathrm{mM} \mathrm{KCl}, 10 \mathrm{mM}$ Tris- $\mathrm{HCl}$ ( $\mathrm{pH} 8.3$ ), $3.0 \mathrm{mM} \mathrm{MgCl}$, $0.2 \mathrm{mM}$ dNTPs, $0.4 \mathrm{mM}$ each primer, $25 \mathrm{ng}$ of genomic DNA, 1.0 unit of Taq DNA polymerase (Invitrogen) and ultra-pure water to adjust the volume to $25 \mu \mathrm{L}$.

The presence or absence of the band corresponding to each pair of primers used was detected in the amplified products in the visualization of the direct gel bands per parent $\left(M_{1}, M_{2}, M_{3}\right.$ and $\left.M_{4}\right)$ and $F_{1}$ progenies $\left(P_{1} \times M_{1}\right.$ and $\mathrm{P}_{1} \times \mathrm{M}_{2}$ ). Products generated in the parents were purified with the Wizard ${ }^{\circledR}$ SV Gel and PCR Clean-Up System kit, and the fragments sequenced by Ludwing Biotechnology. The sequences were compared with those from the NCBI (National Center for Biotechnology Information) database as the BLAST (Basic Local Alignment Search Tool) program (Altschul et al., 1997) for nucleotides after sample sequencing.

The results were compared to GenBank sequences deposited after confirmation of amplification of seeded genotypes, with 16 samples sequenced (four accessions: $\mathrm{M}_{1}, \mathrm{M}_{2}, \mathrm{M}_{3}$ and $\mathrm{M}_{4}$ ) in four primers (LMINO 01/02, LMINO 03/04, LMINO 05/06 and LMINO 07/08) (Table 1).

A dendrogram was constructed from the GenBank sequence data from the INO gene transcription factor to evaluate the similarity between them and the treatments (accessions of seeded A. squamosa and the cultivar of A. cherimola x A. squamosa).

\section{Results and Discussion}

The fruits of all individuals from the $M_{1}$ and $M_{2}$ accessions and $F_{1}$ progenies $\left(P_{1} \times M_{1}\right.$ and $\left.P_{1} \times M_{2}\right)$ had seeds. The seedless characteristic was observed only in the fruits of the male parent $P_{1}$ cultivar Brazilian seedless (Figure 1). These preliminary data suggest a monogenic inheritance with complete dominance-type allelic interaction. The seedlessness of the Annona Brazilian seedless variety was due to the formation of a stenospermal fruit with partially formed seeds due to their abortion after fertilization, as reported for Vitis vinifera and Annona squamosa (Bouquet and Danglot, 1996; Lora et al., 2011; Mendes et al., 2012; Santos et al., 2014). A monogenic inheritance with complete 
dominance-type allelic interaction of this trait in $78 \mathrm{~F}_{1}$ A. squamosa plants (crossing wild-type A. cherimola with another seedless mutant) was also reported (Lora et al., 2011).

The similarity between the $\mathrm{M}_{1}, \mathrm{M}_{2}, \mathrm{M}_{3}$ and $\mathrm{M}_{4}$ sample sequences and those deposited in the GenBank (accession: GU828033.1) for the transcription factor of the INO gene in A. squamosa was high due to the presence of the INO gene and, consequently, of seeds in its fruits (Souza et al., 2010; Varoquaux et al., 2000). Similarity in $100 \%$ of the

Table 1. Fragment size (Size), E-value *, identity (Ident.) and GenBank accession (Access) sequences generated from the amplification of DNA in Annona squamosa accessions with $\mathrm{M}_{1}, \mathrm{M}_{2}$, and $\mathrm{M}_{3}$ seeds and Gefner $\left(\mathrm{M}_{4}\right)$ Annona cherimola $\times$ A. squamosa with the INO gene-specific primers

\begin{tabular}{ccccc}
\hline Sample & $\begin{array}{c}\text { Size } \\
\text { (bp) }\end{array}$ & E-value* & $\begin{array}{c}\text { Ident. } \\
\text { (\%) }\end{array}$ & 1Access *** \\
\hline LMINO 01/02 M & 300 & $9 \mathrm{e} /-108$ & 97 & GU828033.1 \\
LMINO 01/02 M & 300 & $3 \mathrm{e} /-92$ & 99 & GU828033.1 \\
LMINO 01/02 M & 300 & $9 \mathrm{e} /-83$ & 97 & GU828033.1 \\
LMINO 01/02 M & 300 & $1 \mathrm{e} /-27$ & 79 & GU828033.1 \\
LMINO 03/04 M & 290 & $3 \mathrm{e} /-37$ & 100 & GU828033.1 \\
LMINO03/04 M & 290 & $8 \mathrm{e} /-108$ & 99 & GU828033.1 \\
LMINO 03/04 M & 280 & $3 \mathrm{e} /-122$ & 99 & GU828033.1 \\
LMINO 03/04 M & 280 & $1 \mathrm{e} /-120$ & 99 & GU828033.1 \\
LMINO 05/06 M & 500 & $1 \mathrm{e} /-153$ & 100 & GU828033.1 \\
LMINO 05/06 M & 500 & $3 \mathrm{e} /-155$ & 100 & GU828033.1 \\
LMINO 05/06 M & 500 & $5 \mathrm{e} /-152$ & 100 & GU828033.1 \\
LMINO 05/06 M & 500 & $3 \mathrm{e} /-140$ & 97 & GU828033.1 \\
LMINO 07/08 M & 900 & $4 \mathrm{e} /-32$ & 80 & GU828033.1 \\
LMINO 07/08 M & 900 & 0.0 & 99 & GU828033.1 \\
LMINO 07/08 M & 900 & 0.0 & 98 & GU828033.1 \\
LMINO 07/08 M 4 & 800 & 0.0 & 95 & GU828033.1 \\
\hline
\end{tabular}

*E-value: probability of randomly finding the same alignment between two sequences; ${ }^{* *}$ Identity: percentage of identity between the amplified and related product sequences; ${ }^{* * *}$ GenBank accession: accession number of the related body sequence; ${ }^{1}$ More related sequence: sequence with highest homology product= transcription factor of the INO gene in Annona squamosa.
GenBank sequences, added as a standard with one of the sequences sampled, reinforces the hypothesis of INO gene conservation in seeded $A$. squamosa accessions ( $\left.\mathrm{M}_{1}, \mathrm{M}_{2}, \mathrm{M}_{3}\right)$ and in the Gefner cultivar of $A$. cherimola $\times$ A. squamosa (Nachtigal et al., 2005)

The INO gene was amplified with bands in the accessions of the seeded sugar apple, the atemoya cultivar Gefner and in all progeny of the $F_{1}$ population. This gene did not present a band in the Brazilian seedless A. squamosa variety $\left(P_{1}\right)$ (Figure 2). Sequence homology, generated by the amplification of the $\mathrm{M}_{1}, \mathrm{M}_{2}, \mathrm{M}_{3}$ and $\mathrm{M}_{4}$ accessions, was high, with 79 to $100 \%$ similarity to the INO gene transcription factor in A. squamosa (Figure 3). The amplification of the INO gene, from the specific primers for seeded $A$. squamosa, from the A. cherimola $\times A$. squamosa Gefner and from the $\mathrm{F}_{1}$ accessions is due to its conservation in these genotypes as reported for Annonaceae (Souza et al., 2010). On the other hand, the absence of amplification in the Brazilian seedless variety indicates the deletion/discontinuation of this gene, as reported for the 'Thai seedless' variety of A. squamosa (Lora et al., 2011).

The high homology of the sequences generated by the $\mathrm{M}_{1}, \mathrm{M}_{2}, \mathrm{M}_{3}$ and $\mathrm{M}_{4}$ accession amplification indicates that seed presence in $A$. squamosa and probably in atemoya is due to the INO gene. This gene is conserved in species and accessions of the Annona genus, forming seeds in external teguments that may be common to all angiosperm groups (Mcabee et al., 2005; Yamada et al., 2003). The presence of the INO gene and the origin of the external integument appear to have evolved concomitantly by genetically regulating ovule development in association with the evolution of the specific structure of the angiosperms (Mcabee et al., 2005; Lora et al., 2011). The INO expression pattern in Annonaceae is consistent with the conservation of the function of this gene in Arabidopsis, and the absence of the external integument in A. squamosa without seeds (Thai seedless) is associated with the suppression of this gene (Villanueva et al., 1999)

The similarities of the transcription factor of the INO gene in wild $A$. squamosa was observed between the sequences of the 16 samples obtained and the one deposited in the GenBank (accession: GU828033.1) (Figure 3). The INO gene transcription in wild-type $A$. squamosa varieties was not observed in the seedless mutants (Lora et al., 2011). Seedlessness due to INO gene disruption may allow assisted
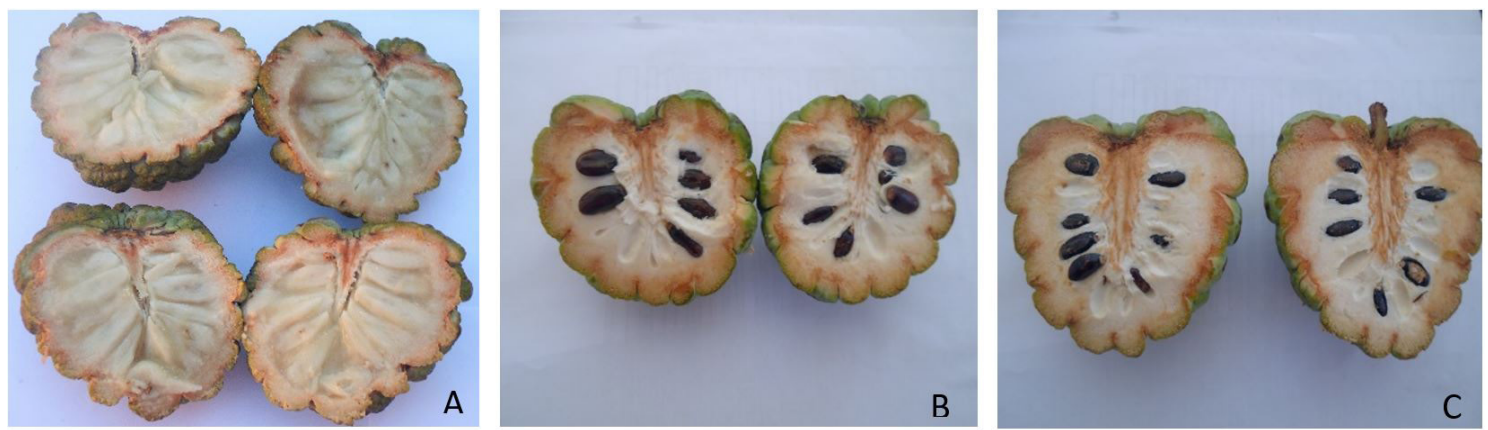

Figure 1. Cross section of the Annona squamosa fruits of the Brazilian seedless cultivar $\left(P_{1}\right)(A)$ and $F_{1}$ generation: $P_{1} \times M_{1}(B), P_{1} \times M_{2}(C)$. 


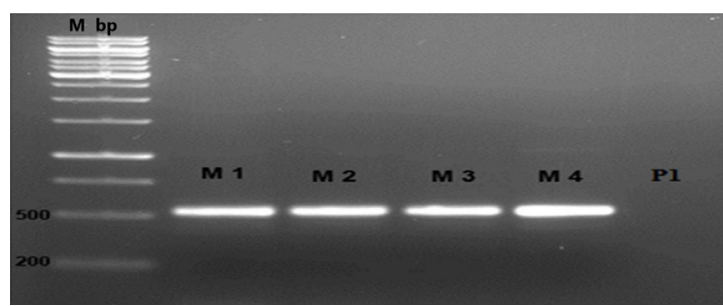

Figure 2. Amplification of Annona squamosa accessions $\mathrm{M}_{1}, \mathrm{M}_{2}, \mathrm{M}_{3}$ 'Gefner' atemoya $\left(\mathrm{M}_{4}\right)$ and seedless A. squamosa 'Brazilian seedless' $\left(\mathrm{P}_{1}\right)$ using the LMINO 05/LMINO 06 primers with a molecular weight amplification product of approximately $600 \mathrm{bp}$ in $1.2 \%$ agarose gel in $1 \mathrm{X}$ TBE buffer. $\mathrm{M}$ bp: $1 \mathrm{~kb}$ molecular weight marker.

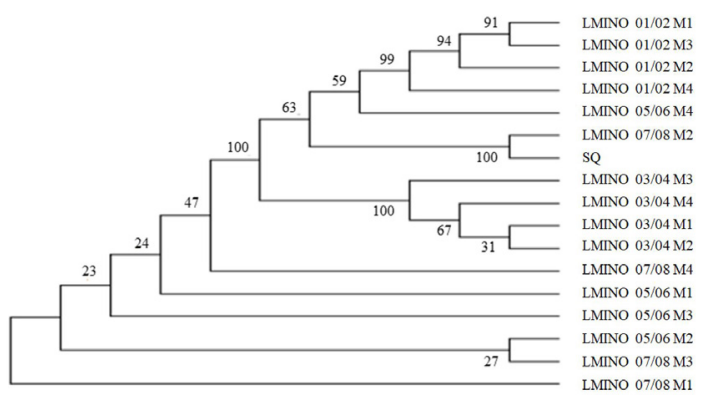

Figure 3. Phylogenetic tree constructed by the distance method using the minimal evolutionary model- parameter and neighbor-joining neighbors clustering algorithm with bootstrap support for 1000 replications. SQ: transcription factor of the INO gene in Annona squamosa accession GU828033.1.

selection by molecular markers using these primers in subsequent generations and backcrosses with the cultivar Gefner to detect seed absence in plants at the seedling stage, consequently reducing costs and time to obtain a new Annonaceae variety (Arif et al., 2010).

The origin of the Thai and Brazilian seedless varieties is not well understood. The 'Brazilian seedless' was first identified in Brazil in 1940 by the agronomist José Chaves da Cunha and its origin has not yet been fully determined but it may have come from a natural mutation or from other parts of the world. Both varieties present the deletion of the INO locus but this does not prove that they belong to the same line and additional studies would need to be performed in order to resolve this question.

\section{Conclusions}

The inheritance of the seeded characteristic is possibly monogenic with complete dominance-type allelic interaction, with the INO gene conserved in seeded A. squamosa cultivars and high sequence homology of the transcription factor of this gene in A. squamosa.

The specific primers LMINO 01/02, LMINO 03/04, LMINO 05/06 and LMINO 07/08 can be used in assisted selection by molecular markers in the identification of $A$. squamosa and $A$. cherimola $\times A$. squamosa seedless cultivars.

\section{Acknowledgements}

The authors would like to thank Fundação de Amparo a Pesquisa do Estado de Minas Gerais (FAPEMIG), the Conselho Nacional de Desenvolvimento Científico e Tecnológico (CNPq) for Research Productivity grants to J Zanuncio, S Nietsche (304231/2018-5) and MCT Pereira (310344/2017-4), and the project was financed in part by the Coordenação de Aperfeiçoamento de Pessoal de Nível Superior (CAPES- Finance Code 001), Brasil. To Dr. Phillip John Villani (University of Melbourne, Australia) revised and corrected the English language used in this manuscript.

\section{References}

ALTSCHUL, S.F., MADDEN, T.L., SCHÄFFER, A.A., ZHANG, J., ZHANG, Z., MILLER, W. and LIPMAN, J.J., 1997. Gapped BLAST and PSIBLAST: a new generation of protein database search programs. Nucleic Acids Research, vol. 25, no. 17, pp. 3389-3402. http:// dx.doi.org/10.1093/nar/25.17.3389. PMid:9254694.

ARIF, I.A., BAKIR, M.A., KHAN, H.A., AL FARHAN, A.H., AL HOMAIDAN, A.A., BAHKALI, A.H., SADOON, M.A. and SHOBRAK, M., 2010. A brief review of molecular techniques to assess plant diversity. International Journal of Molecular Sciences, vol. 11, no. 5, pp. 20792096. http://dx.doi.org/10.3390/ijms11052079. PMid:20559503.

BOUQUET, A. and DANGLOT, Y., 1996. Inheritance of seedlessness in grapevine (Vitis vinifera L.). Vitis, vol. 35, pp. 35-42.

CHEUNG, W.T., HUBERT, N. and LANDRY, B.S., 1993. A simple and rapid DNA microextraction method for plant, animal, and insect suitable for RAPD and other PCR analyses. PCR methods and applications, vol. 3, no. 1, pp. 69-70. http://dx.doi.org/10.1101/ gr.3.1.69. PMid:8220189.

DOYLE, J.J. and DOYLE, J.L., 1990. Isolation of plant DNA from fresh tissue. Focus (San Francisco, Calif.), vol. 12, pp. 13-15.

LORA, J., HORMAZA, J.I., HERRERO, M. and GASSER, C.S., 2011. Seedless fruits and the disruption of a conserve genetic pathway in angiosperm ovule development. Proceedings of the National Academy of Sciences of the United States of America, vol. 108, no. 13, pp. 5461-5465. http://dx.doi.org/10.1073/pnas.1014514108. PMid:21402944.

MCABEE, J.M., KUZOFF, R.K. and GASSER, C.S., 2005. Mechanisms of derived unitegmy among impatiens species. The Plant Cell, vol. 17, no. 6, pp. 1674-1684. http://dx.doi.org/10.1105/ tpc.104.029207. PMid:15849275.

MENDES, H.T.A., COSTA, M.R., NIETSCHE, S., OLIVEIRA, J.A.A. and PEREIRA, M.C.T., 2012. Pollen grain germination and fruit set in 'Brazilian seedless' sugar apple (Annona squamosa L.). Crop Breeding and Applied Biotechnology, vol. 12, no. 4, pp. 277-280. http://dx.doi.org/10.1590/S1984-70332012000400007.

NACHTIGAL, J.C., CAMARGO, U.A. and MAIA, J.D.G., 2005. Efeito de reguladores de crescimento em uva apirênica, cv. BRS Clara. Revista Brasileira de Fruticultura, vol. 27, no. 2, pp. 304-307. http://dx.doi.org/10.1590/S0100-29452005000200029.

PAREEK, S., YAHIA, E.M., PAREEK, O.P. and KAUSHIK, R.A., 2011. Postharvest physiology and technology of Annona fruits. Food Research International, vol. 44, no. 7, pp. 1741-1751. http:// dx.doi.org/10.1016/j.foodres.2011.02.016.

PEREIRA, M.C.T., CRANE, J.H., NIETSCHE, S., MONTAS, W. and SANTOS, M.A., 2014. Reguladores de crescimento na frutificação efetiva e qualidade de frutos partenocárpicos de atemoia 'Gefner'. Pesquisa Agropecuária Brasileira, vol. 49, no. 4, pp. 281-289. http://dx.doi.org/10.1590/S0100-204X2014000400006. 
PEREIRA, M.C.T., NIETSCHE, S., SÃO JOSE, A.R., LEMOS, E.E.P., MIZUBUTSI, G.P., CORSATO, C.F. and ALVARENGA, C.D., 2019. Anonáceas: Pinha (Annona squamosa L.), Atemóia (Annona squamosa $\mathrm{x}$ Annona cherimola Mill.) e graviola (Annona muricata). In: T.J. PAULA-JUNIOR and M. VENZON, eds. 101 culturas: manual de tecnologias agrícolas. Belo Horizonte: EPAMIG, p. 111-123.

QUÍLEZ, A.M., FERNÁNDEZ-ARCHE, M.A., GARCÍA-GIMÉNEZ, M.D. and DE LA PUERTA, R., 2018. Potential therapeutic applications of the genus Annona: local and traditional uses and pharmacology. Journal of Ethnopharmacology, vol. 225, pp. 244-270. http:// dx.doi.org/10.1016/j.jep.2018.06.014. PMid:29933016.

SANTOS, R.C., RIBEIRO, L.M., MERCADANTE-SIMÕES, M.O., COSTA, M.R., NIETSCHE, S. and PEREIRA, M.C., 2014. Stenospermy and seed development in the Brazilian seedless variety of sugar apple (Annona squamosa). Anais da Academia Brasileira de Ciências, vol. 86, no. 4, pp. 2101-2108. http://dx.doi.org/10.1590/00013765201420140206. PMid:25590744.

SOUZA, D.A., MELO, L.C., LIBRELON, S.S., COSTA, M.R., NIETSCHE, S. and PEREIRA, M.C.T., 2010. Identification of hybrids of intra and interspecific crosses in Annonaceae by RAPD markers. Crop Breeding and Applied Biotechnology, vol. 10, no. 2, pp. 110-115. http://dx.doi.org/10.12702/1984-7033.v10n02a02.

VAROQUAUX, F., BLANVILLAIN, R., DELSENY, M. and GALLOIS, P., 2000. Less is better: new approaches for seedless fruit production. Trends in Biotechnology, vol. 18, no. 6, pp. 233
242. http://dx.doi.org/10.1016/S0167-7799(00)01448-7. PMid: 10802558.

VILAR, J.B., FERREIRA, F.L., FERRI, P.H., GUILLO, L.A. and CHEN-CHEN, L., 2008. Assessment of the mutagenic, antimutagenic and cytotoxic activities of ethanolic extract of araticum (Annona crassiflora Mart.1841) by micronucleus test in mice. Brazilian Journal of Biology = Revista Brasileira de Biologia, vol. 68, no. 1, pp. 141-147. http://dx.doi.org/10.1590/S1519-69842008000100020. PMid: 18470389.

VILAR, J.B., FERRI, P.H. and CHEN-CHEN, L., 2011. Genotoxicity investigation of araticum (Annona crassiflora Mart., 1841, Annonaceae) using SOS-Inductest and Ames test. Brazilian Journal of Biology = Revista Brasileira de Biologia, vol. 71, no. 1, pp. 197-202. http://dx.doi.org/10.1590/S1519-69842011000100028. PMid:21437418.

VILLANUEVA, J.M., BROADHVEST, J., HAUSER, B.A., MEISTER, R.J., SCHNEITZ, K. and GASSER, C.S., 1999. INNER NO OUTER regulates abaxial-adaxial patterning in Arabidopsis ovules. Genes E Development, vol. 13, no. 23, pp. 3160-3169. http:// dx.doi.org/10.1101/gad.13.23.3160. PMid:10601041.

YAMADA, T., ITO, M. and KATO, M., 2003. Expression pattern of INNER NO OUTER homologue in Nymphaea (water lily family, Nymphaeaceae). Development Genes and Evolution, vol. 213, no. 10, pp. 510-513. http://dx.doi.org/10.1007/s00427-003-0350-8. PMid:12928899. 